\title{
THE EFFECT OF CORPORATE SOCIAL RESPONSIBILITY DISCLOSURE ON THE COMPANY'S FINANCIAL PERFORMANCE (An Empirical Study on Mining Companies enlisted in ISE during 2014)
}

\author{
Eskasari Putri $^{1)}$, Arief Budhi Dharma ${ }^{2)}$, and Rina Trisnawati ${ }^{3)}$ \\ 1,2,3) Accounting Study Program, Faculty of Economics and Business, \\ Surakarta Muhammadiyah University \\ Email: 1)ep122@ums.ac.id ${ }^{2)}$ ariefbudhidharma1@gmail.com \\ ${ }^{3)}$ rina.trisnawati@ums.ac.id
}

\begin{abstract}
This research aimed to provide empirical evidence that the disclosure of Corporate Social Responsibility affected significantly the Return On Asset (ROA), Return On Equity (ROE), and Return On Sales (ROS) in mining companies enlisted in ISE during 2014. The sample of research was taken using purposive sampling method; the data was obtained from www.idx.com. The sample of research consisted of companies in mining sector during 2014. There were 33 companies fulfilling the criteria of sample. The method of analyzing data used in this research was a simple regression analysis. Considering the result of research using $t$-test, it could be found that the disclosure of Corporate Social Responsibility affected ROA and ROE positively and insignificantly, while it affected ROS positively and significantly. The recommendations given to the company were that the company should disclose the activities related to its Corporate Social Responsibility more transparently in its annual report, Corporate Social Responsibility indeed needed large cost, but it could benefit the company as well by improving the company's image and legitimacy, so that the company could make it the corporate strategy.
\end{abstract}

Keywords: CSR, ROA, ROE, ROS

\begin{abstract}
Abstrak
Penelitian ini bertujuan untuk memberikan bukti empiris bahwa Corporate Social Responsibility memengaruhi secara signifikan Return On Asset (ROA), Return On Equity (ROE), dan Return On Sales (ROS) di perusahaan pertambangan yang terdaftar di ISE selama 2014. Sampel dari penelitian diambil dengan menggunakan metode purposive sampling; datanya diperoleh dari www.idx.com. Sampel penelitian ini terdiri dari perusahaan-perusahaan di sektor pertambangan selama 2014. Terdapat 33 perusahaan yang memenuhi kriteria sampel. Metode analisis data yang digunakan dalam penelitian ini adalah analisis regresi sederhana. Hasil penelitian menggunakan uji-t menemukan bahwa Corporate Social Responsibility memengaruhi ROA dan ROE secara positif dan tidak signifikan, sedangkan hal tersebut mempengaruhi ROS secara positif dan signifikan. Rekomendasi yang dapat diberikan kepada perusahaan adalah perusahaan harus mengungkapkan kegiatan yang terkait dengan Tanggung Jawab Sosial Korporatnya secara lebih transparan dalam laporan tahunannya, Tanggung Jawab Sosial Perusahaan memang membutuhkan biaya besar, tetapi dapat menguntungkan perusahaan juga dengan meningkatkan citra dan legitimasi perusahaan sehingga perusahaan dapat menjadikannya sebagai strategi perusahaan.
\end{abstract}

Kata kunci: CSR, ROA, ROE, ROS

\section{INTRODUCTION}

Nowadays, many environmental problems result from the more natural resource exploitation for corporate operational activity. The problems in the corporate operational activity resulting in environmental issues such as soil damage, plant damage, environmental damage and other environmental annoyance makes many parties feeling disturbed; in addition, the company itself is considered as paying less attention to the problem resulting from its corporate activity. Therefore, the company is required to implement its social responsibility to environment, community and stakeholders in order to create the balance between corporate activity and its environment.

The nature in West Java faces a severely damaging threat. Wahana Lingkungan Hidup (Living Environment Organization, thereafter called Walhi) of West Java found 36,093 
hectares karsts area specified as geological protection area damaged due to mining exploitation. Whereas, the karsts landscape stores water sources, natural and historical caves constituting the protected natural pledge. "Such the wide area is distributed in some hills and mountains in 11 regencies: Pangandaran, Ciamis, Cirebon, Kuningan, Tasikmalaya, Bandung Barat, Bogor, Sukabumi, Purwakarta, Sukabumi and Karawang", explained the executive director of West Java Walhi, Dadan Ramdan, on Saturday ((28/3/2015) (source: news.detik.com).

A company should have Corporate Social Responsibility. Corporate Social Responsibility is a form of sustainability reporting making the company no longer facing the responsibility standing on single bottom line, namely the corporate value reflected on financial condition only. However, corporate responsibility should stand on triple bottom lines paying attention to social and environment problems as well (Husnan, 2013).

Hadi (2002) stated that the company's social partiality to community (social responsibility) contains both social and economic motives. Social responsibility has social both social and economic consequences. The result of Hadi's (2009) study showed that social cost the company spends is beneficial to improve social performance, namely, improving legitimacy and reducing the stakeholders' complaint. In addition, social cost (the cost of company's partiality to stakeholders) also improves image, in both commodity and capital markets. This research is supported by Memed's (2002) study finding that social cost improves the economic performance of company participating in clean river program (Hadi, 2011:65).

Although social responsibility has social and economic consequences, in fact the companies have varying point of views. Such the different perspectives exist diametrically, in which some companies consider corporate social responsibility as not their obligation, even social responsibility contains relatively large cost that disturbs the company's profitability. Meanwhile, some business performer groups consider that social responsibility is a longterm investment and has advantage of improving image and legitimacy, so that it can be the basic construction of company strategy (Hadi, 2011:66).

Corporate social responsibility (CSR) is now starting to be practiced by companies in running their business. Since the enactment of Article 74 of Law No.40 of 2007 about Limited Incorporation, the awareness of undertaking corporate social responsibility or called CSR begins to develop in Indonesia. This law states that: (1) the corporation running its business activity in natural resource and/or natural resource-related areas obligatorily undertakes its social and environmental responsibility. (2) Social and environmental responsibility as intended in clause (1) is the corporation's obligation that is budgeted and taken into account as the corporation cost, the implementation of which is conducted by taking feasibility and reasonability into account. (3) The corporation not undertaking obligation as mentioned in clause (1) will be imposed with sanction corresponding to the legislation. (4) Further stipulation about social and environmental responsibility is governed by government regulation.

One type of companies mentioned in this law is mining company. Mining company is the one whose primary operation affects significantly the natural resource that in its activity very likely will damage the environment when its operational objective emphasizes more on profit only (Candrayanthi and Saputra, 2013).

Annual report is used as one of media used to disclose the application of corporate social responsibility. Annual report is the communication medium of company with external party. It has been recommended in PSAK No.1 of 2009 in paragraph 9 about Financial Report Presentation, in Financial Report Responsibility section stating that: "The company can present supplemental report such as the report on living environment and value added statement as well, particularly for industry in which living environment factors play an important role and for industry considering its employees as the report user group playing important role". 
Financial performance can represent the corporate financial condition and welfare in certain period of time. The assessment on financial performance is usually conducted through financial ratio analysis. Financial ratio analysis is used to measure and to assess the work performance in financial division of a company in certain period of time (Rosiliana et al, 2014). The ratios used in this research are Return On Asset), ROE (Return On Equity), and ROS (Return On Sales).

Considering the statement above, the author is interested in conducting a research entitled "THE EFFECT OF CORPORATE SOCIAL RESPONSIBILITY DISCLOSURE ON THE COMPANY'S FINANCIAL PERFORMANCE (An Empirical Study on Mining Companies enlisted in Indonesian Stock Exchange during 2014)".

\section{LITERATURE REVIEW HYPOTHESIS DEVELOPMENT}

AND

Legitimacy theory states that the company attempts to act continuously corresponding to borders and norms within society; for that attempt, the company tries to make its activity acceptable to the external parties' perception (Deegan,2000). The company tries to justify its presence within society with its activity legitimacy (Naseretal.,2006). Legitimacy theory has been used in accounting study to develop the social and responsibility disclosing theory (e.g. Naser etal., 2006 and Rustiarini, 2011).

Ghozali and Chariri, (2007 in Purnawati, 2012) stated that legitimacy theory builds on a social contract occurring between company and society, in which the company operates and uses economic source. Legitimacy theory, according to Guthrie and Parker, (1989 in Purnawati, 2012), explains that an organization in conducting its operational activity should show off its behavior consistent with social values. Conducting CSR activity and disclosure is one way to influence the community's perception on the operational activity the company conducts.

Return On Asset (ROA) is the ration used to measure the mining company management's ability of obtaining profit entirely. Return On
Asset (ROA) or often called Return On Investment (ROI) shows how much net profit can be obtained from entire wealth the company has. For that reason, after-tax profit value and (mean) corporate wealth are used (Husnan and Pudjiastuti, 2006:74), while Return On Sales is the ratio to measure the comparison between after-tax net profit and net sale (Husnan, 2013). The high Return On Sales indicates the company's ability of yielding high profit in certain sale level, and vice versa.

Kamaludin (2010) conducted a research on the effect of corporate social responsibility on corporate profitability and reputation. This result found that CSR affects significantly ROA in high-profile company, and does not affect significantly ROE in high- and lowprofile companies. Meanwhile, CSR affects significantly the corporate reputation (image) in both high- and low-profile companies.

Novi (2012) conducted a research on the effect of Corporate Social Responsibility on financial performance. The result of research shows that the relationship between Corporate Social Responsibility and financial performance is positive.

Alit Candrayanthi and Dharma (2013) conducted a research on the effect of CSR disclosure on the company performance. They found that CSR affected ROA and ROE significantly, while it affected NPM insignificantly.

Kadek Rosiliana et al. (2014) conducted a research on the effect of Corporate Social Responsibility on the company's financial performance. They found that CSR affected partially ROA and ROS positively and significantly, but it affected ROE insignificantly.

Chusnul Khitam (2014) studied the effect of Corporate Social Responsibility on the company's financial performance. This study found that corporate social responsibility affected the company's financial performance positively and significantly.

Considering the previous studies, the author formulated the following hypotheses: 
$\mathrm{H}_{1}$ : Corporate Social Responsibility disclosure affects ROA (return on asset).

$\mathrm{H}_{2}$ : Corporate Social Responsibility disclosure affects ROE (return on Equity).

$\mathrm{H}_{3}$ : Corporate Social Responsibility disclosure affects ROS (return on Sales).

\section{RESEARCH METHOD}

In this research, the author employed secondary data; the data was taken from official website www.idx.com publishing officially the financial statement and annual report of go-public companies in Indonesia. Considering the data of mining companies enlisted in ISE in 2014, there are 41 companies. However, this company used only the data of companies corresponding to the criteria specified by the author. This research took the sample from the mining companies in 2014 period.

The variable used in this research included Corporate Social Responsibility as independent variable and return on asset,return on Equity and return on Sales as the dependent one. This research used Corporate Social Responsibility as independent variable.

The calculation of Corporate Social Responsibility Disclosure (CSRD) was conducted using dummy variable:

\section{Where}

score 0: when the company does not disclose the item in the checklist

score 1: when the company discloses the item in the checklist

The number of items likely fulfilled by companies consisted of 79 items. The index calculation is as follows:

Index $=\frac{n}{k} \mathrm{X} 100 \%$

Where:

$\mathrm{n}=$ the number of disclosure items fulfilled

$\mathrm{n}=$ the number of all disclosure items fulfilled
The dependent variable in this research is expressed with $\mathrm{Y}$. The financial performance of company consists of: ROA, ROE, and ROS, obtained from annual financial statement of mining companies, during research period. The formulas of ROA, ROE, and ROS are as follows:

$$
\begin{aligned}
& \mathrm{ROA}=\frac{\text { after }- \text { tax net } \text { profit }}{\text { Total Asset }} \times 100 \% \\
& \mathrm{ROE}=\frac{\text { after-tax net profit }}{\text { total capital }} \times 100 \% \\
& \mathrm{ROS}=\frac{\text { after-tax net profit } \text { tal }}{\text { Total sale }} \times 100 \%
\end{aligned}
$$

The sampling method used in this research was purposive sampling method, in which there were 33 companies fulfilling the criteria of sample. The sample of research included the mining companies enlisted in Indonesia Stock Exchange in 2014. The data were collected using documentation and library study methods.

The analysis in this research was conducted using statistic descriptive test. Statistic descriptive test is used to find out the level of Corporate Social Responsibility (CSR) disclosure and profitability in mining companies enlisted in ISE. The measurement used in this study included minimum value, maximum value, mean, and standard deviation. Classical assumption test includes normality and heteroscedasticity. This classical assumption test aims to find out and to examine the feasibility of regression model used in this research. This test is intended to ensure that in the regression model used, there is no multicolinearity and heteroscedasticity, and to ensure that the data resulted is distributed normally (Ghozali, 2006).

Normality test is intended to examine whether or not in regression model, the residual variable has normal distribution. As we know, $\mathrm{t}$ - and F-tests assume that residual value follows normal distribution. If this assumption is broken, the statistic test would become invalid for the small number of samples. In principle, normality can be detected by considering the data (point) distribution on diagonal axis in the chart or by seeing the 
residual histogram. Normality test with graph (chart) can be misleading, because it will seem to be normal visually, while it is otherwise actually. For that reason, it is recommended to use statistic test in addition to graphic test.

To detect the data normality, KolmogorovSmirnov (K-S) test was used. Decision making was conducted based on probability (Asymptotic significance) (Singgih Santoso, 2003 in Novi, 2012), as shown below:

If probability > 0.05 (significance level used), its population distribution would be normal.

If probability $<0.05$ (significance level used), its population distribution would not be normal.

Heteroscedasticity, according to Ghozali Imam (2011), is aimed at examining whether or not in regression model there is a difference of variance and residual between one observation and another. If variance and residual in one observation are the same as those in another, it is called homoscedasticity and when they are different, it is called heteroscedasticity. The good regression model is homoscedasticity or there is heteroscedasticity. The way of detecting the presence of heteroscedasticity is to see the plot chart between predicted value of dependent variable (ZPRED) and its residual (SRESID).

Through detecting the presence of certain pattern in scatter plot chart between SRESID and ZPRED it can be seen that $\mathrm{X}$ axis is the predicted $\mathrm{Y}$, and $\mathrm{Y}$ axis is residual (predicted $\mathrm{Y}$ - actual Y) that has been studentized.

The rationales of analysis are as follows:

1. If there is a certain pattern such as the point existing creating a regular (wavy, widening and then narrowing) certain pattern, it indicates that heteroscedasticity has occurred.

2. If there is no obvious pattern, and the points are not distributed above and below 0 (zero) on $\mathrm{Y}$ axis, heteroscedasticity does not occur.

The data collected were then analyzed using statistical analysis instrument, simple regression analysis, as follows:

$$
\begin{aligned}
& Y_{1=\alpha+\beta \mathrm{X}+\mathrm{e}} \\
& Y_{2=\alpha+\beta \mathrm{X}+\mathrm{e}} \\
& Y_{3=\alpha+\beta \mathrm{X}+\mathrm{e}}
\end{aligned}
$$

Where:

$$
\begin{array}{ll}
Y_{1} & =\text { Return On Asset } \\
Y_{2} & =\text { Return On Equity } \\
Y_{3} & =\text { Return On Sales } \\
\alpha & =\text { Constant } \\
\beta & =\text { Coefficient of Regression } \\
\mathrm{X} \quad & =\text { Corporate Social Responsibility } \\
\mathrm{E} \quad=\text { Error Term, the level of predictor } \\
\text { error in research. }
\end{array}
$$

T- statistic test is used to show the extent to which one independent variable explains the variation of dependent variable individually. The rationales of decision making are as follows:

1. $t_{\text {hitung }} \geq t_{\text {tabel }}$, therefore $H_{0}$ is not supported, $H_{\propto}$ is supported, meaning there is a significant effect.

2. $t_{\text {hitung }} \leq t_{\text {tabel }}$, therefore $H_{0}$ is supported $H_{\propto}$ is not supported, meaning that there is insignificant effect.

T-test can also be conducted by considering the t- significance value of individual variables in the output of regression result using SPSS at significance level $0.05(\alpha=5 \%)$. If significance value is more than $\alpha$, the hypothesis is not supported (coefficient of regression is not significant), meaning that independent variable does not affect partially dependent variable significantly. If significance value is less than $\alpha$, the hypothesis is supported (coefficient of regression is significant), meaning that independent variable affects partially the dependent variable significantly.

Ghozali Imam (2011) stated that the coefficient of determination $\left(\mathrm{R}^{2}\right)$ essentially measures the extent to which the model can explain the variation of dependent variable. The coefficient of determination is between zero and one. The smaller $\mathrm{R}^{2}$ value means that the independent 
variables' ability of explaining the variation of dependent variable is very limited. The value close to one means that independent variables provide nearly all information needed to predict the variation of dependent variable.

\section{RESULT AND DISCUSSION}

Considering the data obtained from the official website of Indonesia Stock Exchange, it can be obtained the data of 41 mining companies during 2014. The sample was taken using purposive sampling method with the following criteria: 1) the companies are enlisted in ISE during 2014,2 ) they provide complete annual reports per December 31, 2014, 3) they disclose their Corporate Social Responsibility activities in annual report of 2014,4 ) they have complete data related to the variables used in the research, and 5) the financial statement is presented in rupiah currency. Thus, finally 33 companies were obtained as the sample corresponding to the specified criteria.

Based on the result of data processing using statistic descriptive method, it can be seen that 33 companies were used as the sample of research. The mean value of CSR disclosure is 0.3494 or $34.94 \%$ with standard deviation of 0.1742 or $17.42 \%$ meaning that the variation of data was not large (less than $30 \%$ of mean value). There were 15 companies disclosing CSR above $34.94 \%$ mean value and the rest of 18 companies disclosed CSR below the mean value. The lowest value of CSR disclosure was 0.05 or $5 \%$ occurring in Cita Mineral Investindo Tbk and the highest one was $0.75 \%$ in Aneka Tambang (Persero) Tbk or called ANTM constituting the State-Owned Enterprise (BUMN).

Considering the statistic descriptive analysis, it can be found that the mean value of ROA is 4.088 with standard deviation of 7.3330 meaning that the variation of data was very large (more than $30 \%$ of mean value). The lowest ROA value was $-13.7 \%$ occurring in CitaMineral Investindo Tbk and the highest ROA was $19.2 \%$ occurring in Mitrabara Adiperdana Tbk companies.

Considering the statistic descriptive analysis, it can be found that the mean value of ROE is 6.221with standard deviation of18.32 meaning that the variation of data was very large (more than $30 \%$ of mean value). The lowest ROE value was -63.0 occurring in Apextindo Pratama Duta Tbk and the highest ROEwas 37.2 occurring in Mitrabara Adiperdana Tbk companies.

Considering the statistic descriptive analysis, it can be found that the mean value of ROS is 2.694with standard deviation of 37.09 meaning that the variation of data was very large (more than $30 \%$ of mean value). The lowest ROS value was -184.0 occurring in Cita Mineral Investindo Tbk and the highest ROEwas 37.9 occurring in Mitra Investindo Tbk companies.

Considering the regression test statistically, for the equation it can be seen that the constant $\alpha$ of -0.866 meaning that when the company does not disclose CSR, ROA will decrease by $0.866 \%$, and $\beta$ value is positive 14.178 meaning that every $1 \%$ increase in Corporate Social Responsibility will increase ROA of $14.178 \%$ with the assumption that other variables are constant. From the result of t-test analysis, it can be seen that significance value is $0.055>0.05$, indicating that corporate social responsibility does not affect ROA significantly. It is because in the company's CSR disclosure, there is an additional cost to undertake the corporate social responsibility. The Adjusted $\mathrm{R}^{2}$ value is 0.085 or $8.5 \%$, indicating that $8.5 \%$ of ROA variable is explained by CSR, while the rest of $91.5 \%$ is explained by other factors out of CSR. So, it can be concluded that $\mathrm{H}_{1}$ is not supported meaning that the more the companies disclose CSR, the smaller is the ROA.

Considering the regression test statistically, for the second equation it can be seen that the constant $\alpha$ of -0.849 meaning that when the company does not disclose CSR, ROE will decrease by $0.849 \%$, and $\beta$ value is positive 20.235 meaning that every $1 \%$ increase in Corporate Social Responsibility will increase ROE of $20.235 \%$. From the result of t-test analysis, it can be seen that significance value is $0.283>0.05$, indicating that corporate social responsibility does not affect ROE significantly. It is because in the company's CSR disclosure, the disclosure of corporate social responsibility takes much cost, in which 
the very large cost will reduce the company's income. The Adjusted $\mathrm{R}^{2}$ value is 0.006 or $0.6 \%$, indicating that $0.6 \%$ of $\mathrm{ROE}$ variable is explained by CSR, while the rest of $99.4 \%$ is explained by other factors out of CSR. So, it can be concluded that $\mathrm{H}_{2}$ is not supported meaning that the more the companies disclose CSR, the smaller is the ROE.

Considering the regression test statistically, it can be seen that the constant $\alpha$ of -29.906 meaning that when the company does not disclose CSR, ROS will decrease by $29.906 \%$, and $\beta$ value is positive 77.882 meaning that every $1 \%$ increase in Corporate Social Responsibility will increase ROS of $77.885 \%$. From the result of t-test analysis, it can be seen that significance value is $0.036<0.05$, indicating that corporate social responsibility affects ROS significantly. Corporate Social Responsibility exerts positive effect on the company, in which conducting CSR will improve the community's trust in the company thereby building good image for the company. The good corporate image and the community's trust in the company will improve the consumers' purchasing interest, thereby improving the sale and the profit of company. The Adjusted $\mathrm{R}^{2}$ value is 0.106 or $10.6 \%$, indicating that $10.6 \%$ of ROS variable is explained by CSR, while the rest of $89.4 \%$ is explained by other factors out of CSR. So, it can be concluded that $\mathrm{H}_{3}$ is supported meaning that the more the companies disclose CSR, the higher is the ROE.

\section{CONCLUSION}

Considering the result of research and discussion mentioned earlier, the following conclusions can be drawn. First, The effect of CSR on ROA. The result of test shows that Corporate Social Responsibility affects ROA positively and insignificantly. So, it can be concluded that through disclosing CSR, the performance of company measured with ROA will decrease. Second, The effect of CSR on ROE. The result of test shows that Corporate Social Responsibility affects ROE positively and insignificantly. So, it can be concluded that through disclosing CSR, the performance of company measured with ROE will decrease. Third, The effect of CSR on ROS. The result of test shows that Corporate Social Responsibility affects ROS positively and significantly. So, it can be concluded that through disclosing CSR, the performance of company measured with ROS will increase.

\section{RECOMMENDATION}

Considering the result of research conducted, the author gives the following inputs that are expected to be beneficial and the matter of consideration to those interested: first, To the companies, it is recommended to disclose more transparently the activities related to corporate social responsibility in their annual report because it will exert good effect on the corporate image; in addition, CSR has been included into the Law No.40 of 2007, particularly in article 74, about limited incorporation. Second, Corporate Social Responsibility, indeed, needs substantial cost, but it can also benefit the company by improving its image and legitimacy so that the company can make it the corporate strategy. Third, The company is expected to plan distinctive cost budget for Corporate Social Responsibility so that it will not disturb the stability of profitability, particularly ROA and ROE, of company; thus, the company can keep implementing Corporate Social Responsibility activities duly as mandated in the Law.

\section{REFERENCES}

Achmad Zaenuddin. 2007. Faktor-Faktor Yang Berpengaruh Terhadap Praktek Pengungkapan Sosial Dan Lingkungan Pada Perusahaan Manufaktur Go Publik. Tesis. Universitas Diponegoro.

Anggraini, Fr. Reni Retno. 2006. Pengungkapan Informasi Sosial yang Mempengaruhi Pengungkapan Informasi Sosial dalam Laporan Keuangan Tahunan (Studi Empiris pada Perusahaan-Perusahaan yang terdaftar di Bursa Efek Jakarta). Simposium Nasional Akuntansi IX. Padang: h:1123-1135.

Candrayanthi, Alit dan Saputra, Dharma. 2013. "Pengaruh Pengungkapan Corporate Social Responsibility Terhadap Kinerja 
Keuangan Perusahaan”. Bali: Jurnal Akuntansi Universitas Udayana.

Deegan, C.2000. FinancialAccounting Theory.NSW:McGraw-HillAustralia.

Khitam, Chusnul. 2014. "Pengaruh Pengungkapan Corporate Social Responsibility Terhadap Kinerja Keuangan Perusahaan (study kasus pada perusahaan pertambangan yang terdaftar di BEI tahun 2011-2013)”.

Ghozali, Imam. 2006. Analisis Multivariate dengan Program SPSS. Edisi Ke 4. Badan Penerbit Universitas Diponegoro. Semarang.

Ghazali, Imam. 2011. Aplikasi Analisis Multivariate dengan Program IBM SPSS 19. Badan Penerbit UNDIP. Semarang

Hadi, Nor. 2009. Corporate Social Responsibility, Graha Ilmu.Yogyakarta.

Hadi, Nor. 2011. Corporate Social Responsibility, Graha Ilmu.Yogyakarta.

Husnan, Saud dan Pudjiastuti, Enny. 2006. Dasar-dasar Manajemen Keuangan. Edisi ke 5. UPP STIM YKPN. Yogyakarta

Husnan, Ahmad. 2013. Pengaruh Corporate Social Responsibility (CSR Disclosure) Terhadap Kinerja Keuangan Perusahaan. Skripsi. Universitas Diponegoro: Semarang.

http://notcupz.blogspot.com/2011/06/tanggung -jawab-sosial-perusahaan.html diakses pada tgl 22.09.2015 jam 10:38

https://id.wikipedia.org/wiki/Tanggung_jawab _sosial_perusahaan di akses pada tgl 22.09.2015.jam 10:34

https://isharyanto.wordpress.com/derapekonomi-publik/csr-sejarahpertumbuhannya/ di akses pada tgl 22.09.2015 jam 10:45

Indriantoro, Nur dan Supomo, Bambang. 2002. Metodologi Penelitian Bisnis untuk Akuntansi dan Manajemen". Yogyakarta. BPFE.
Indrawan, Danu Candra. 2011. Pengaruh Corporate Social Responsibility Terhadap Kinerja Perusahaan. Skripsi. Universitas Diponegoro: Semarang.

Kusumadilaga, Rimba. 2010. "Pengaruh Corporate Social Responsibility Terhadap Nilai Perusahaan dan Profitabilitas Sebagai Variabel Moderating (study empiris pada perusahaan manufaktur yang terdaftar di bursa efek Indonesia)". Semarang: Skripsi Universitas Diponegoro.

Kamaludin. 2010. "Pengaruh Pengungkapan Corporate Social Responsibility Terhadap Profitabilitas dan Reputasi Perusahaan (study empris pada perusahaan yang terdaftar di bursa efek Indonesia)". Jakarta: Skripsi Universitas Negri Syarif Hidayatullah.

Nur, Marzully dan Priantinah, Denies. 2012. "Analisis Faktor - factor yang Mempengaruhi Pengungkapan Corporate Social Responsibility di Indonesia (study empiris pada perusahaan yang berkategori hight profile yang listing di bursa efek Indonesia)". Yogyakarta.: Jurnal Nominal Vol. 1 No. 1. Universitas Negeri Yogyakarta.

Pemerintah Republik Indonesia. UndangUndang RI Nomor 40 Tahun 2007 pasal 74 ayat (1), (2), (3), (4) tentang Perseroan Terbatas

Resturiyani, Novi. 2012. "Pengaruh Pengungkapan Corporate Social Resposibility Terhadap Kinerja Keuangan”. Bandung.Skripsi Universitas Pasundan.

Rosiliana, Adi Yuniarta, dan Dharmawan Ari. 2014. "Pengaruh Corporate Social Resposibility Terhadap Kinerja Keuangan Perusahaan (Study Empiris Pada Perusahaan LQ45 Di Bursa Efek Indonesia periode 2008 - 2012)'. Bali: Jurnal Akuntansi Vol. 2 No. 1. Universitas Ganesha.

Sugiyono,2009. Metode Penelitian Bisnis. Cetakan Keenam. Bandung:CV. Alfabeta. 
Syahnaz, Melisa. 2012. "Pengaruh Corporate Social Responsibility Terhadap Kinerja Keuangan Perusahaan Perbankan”. Malang: Jurnal Akuntansi Universitas Brawijaya.

Tanudjaja, Bing Bedjo. 2006. "Perkembangan Corporate Social Resposibility di Indonesia”. Surabaya: Jurnal Desaig Komunikasi Visual Vol. 8 No. 2. Universitas Kristen Petra.

Untung, Hendrik Budi, 2008. Corporate Social Responsibility, sinar Grafika. Jakarta.

Wibisono, Yusuf. 2007. "Membedah Konsep dan Aplikasi Corporate Social Responsibility", Fascho Publising. Gresik.

www.google.com

news.detik.com

www.idx.com 